\title{
Optimasi Pemotongan Besi Tulangan Pada Pekerjaan Struktur Menggunakan Metode Linear Programming
}

\author{
Jajang Atmaja*1, Fauna Adibroto $^{2}$, Nurul Hidayah ${ }^{3}$ \\ 1,2 Jurusan Teknik Sipil, Politeknik Negeri Padang, Kampus Limau Manis, Padang \\ ${ }^{3}$ Program Studi Manajemen Rekayasa Konstruksi, Jurusan Teknik Sipil, Politeknik Negeri Padang \\ E-mail: ${ }^{1}$ jajangatmaja@ymail.com
}

Received 19 September 2020; Reviewed 14 October 2020; Accepted 12 November 2020

Journal Homepage: http://jurnal.borneo.ac.id/index.php/borneoengineering

\begin{abstract}
In construction projects, (reinforcing steel was very important material especially in the case work. The number of material wasting can not be avoided in the-fact so effected the waste of work costs that was incurred by the constructor. The steel bar material was one of the materials with a high price on the market. The one solution for reducing the number of (the) steel bar material wasting and optimize steel bar cutting then find out the number of steel bars that were needed with minimal cutting was Linear Programming. The method had been used in this research was Linear Programming with in help of the Solver Add-In program in Microsoft Excel. The research was conducted on a 3-stories building construction project, namely Puskesmas Kampung Dalam, Kabupaten Padang Pariaman. The activies had been considered in this research covered all steel bars work at foundations, sloof, columns, beams and slabs. Results this research that steel bars using the linear programming method of 5.76\%. the percentage before optimization was 13.94\%. The demand for bars in the field was $32885.06 \mathrm{~kg}$, by applying the linear programming method was $30019.78 \mathrm{~kg}$, savings in $8.71 \%$. The costs that can be saved after optimization using the Linear Programming method for foundation work, sloof, column, beam and floor plate is $R p$ 33,094,076.
\end{abstract}

Keywords: reinforcing bars, reinforcing optimization, steel bar wasting, linear programming

\begin{abstract}
Abstraks
Pada proyek konstruksi, besi tulangan merupakan material yang sangat penting dalam pelaksanaan pekerjaan konstruksi. Sisa material besi tidak dapat dihindari di lapangan, sehingga besarnya angka sisa material tak terpakai berpengaruh pada biaya yang dikeluarkan, karena material besi merupakan salah satu material dengan harga tinggi di pasaran. Salah satu solusi memperkecil angka sisa material besi yaitu dengan melakukan optimasi pemotongan besi untuk mendapatkan jumlah potongan sesuai kebutuhan dengan sisa pemotongan seminimal mungkin. Metode yang digunakan yaitu Linear Programming dengan bantuan program Solver Add-In pada Microsoft Excel. Penelitian dilakukan pada proyek pembangunan gedung 3 lantai yaitu Puskesmas Kampung Dalam, Kab. Padang Pariaman. Pekerjaan yang ditinjau mencakup pekerjaan pembesian pada pondasi, sloof, kolom, balok dan plat lantai. Hasil penelitian, waste besi setelah dilakukan optimasi pemotongan besi tulangan menggunakan metode linear programming didapatkan persentase sebesar 5,76\%. Sedangkan persentase waste besi sebelum dilakukan optimasi yaitu sebesar 13,94\%. Kebutuhan besi di lapangan sebesar 32885,06 kg, sedangkan kebutuhan besi dengan menerapkan metode linear programming yaitu sebesar 30019,78 kg, terjadi penghematan kebutuhan besi sebesar $8,71 \%$. Besarnya biaya pelaksanaan yang dapat dihemat setelah dilakukan optimasi menggunakan metode Linear Programming pada pemotongan besi tulangan pekerjaan pondasi, sloof, kolom, balok dan plat lantai yaitu sebesar Rp 33.094.076.
\end{abstract}

Keywords: besi tulangan, optimasi tulangan, waste besi, program linear 


\section{Pendahuluan}

Salah satu dampak negatif dari pembangunan sebuah konstruksi adalah terbentuknya sisa material hasil pekerjaan. Sisa material merupakan bahan yang sudah tidak terpakai untuk proyek tersebut. Pada dasarnya sisa material dapat menjadi hal yang merugikan bagi konstruksi karena bila tidak dikelola dengan baik maka banyak biaya konstruksi yang terbuang. Dengan pengoptimalan yang tepat maka sisa material yang terbentuk diharapkan dapat diminimalisir, Waluyo (2017).

I Gusti Putu Adi (2018) menjelaskan bahwa sisa material konstruksi dapat didefinisikan sebagai sesuatu yang sifatnya berlebih dari yang disyaratkan baik itu berupa pekerjaan maupun material konstruksi yang tersisa, tercecer, rusak sehingga tidak dapat digunakan lagi sesuai fungsinya. Salah satu material konstruksi dengan kebutuhan yang sangat tinggi dalam proyek yaitu besi tulangan. (Farmoso, CT dalam SLES Sabry, 2013) menyatakan bahwa material besi beton merupakan material yang memiliki persentase terhadap biaya tertinggi yaitu berkisar 20\%-30\%. Dengan demikian tingginya angka sisa material besi tentunya menimbulkan kerugian yang cukup besar terhadap biaya pelaksanaan konstruksi. Salah satu solusi yang dapat dilakukan untuk meminimalisasi sisa material besi yaitu melakukan optimasi pemotongan besi. Penelitian dilakukan pada proyek pembangunan gedung 3 lantai yaitu Puskesmas Kampung Dalam, Kab. Padang Pariaman untuk melihat seberapa besar penghematan material besi yang dapat dihasilkan. Metode yang digunakan yaitu metode Linear Programming. Hasil yang didapatkan akan di bandingkan hasil sebelum dan sesudah menggunakan metode ini.

Menurut SLES Sabry (2013) pada proyek gedung Sekretariat Daerah Kota Surakarta, untuk membuat model pemotongan tulangan pada plat lantai untuk menghasilkan waste sekecil mungkin digunakan metode program linear. Metode program linear yang diterapkan adalah metode simpleks dengan bantuan Add-In Solver pada Microsoft Excel. Hasil optimasi yang dilakukan menunjukkan pengurangan waste atau terdapat penghematan sebesar $12,516 \%$ pada pemotongan tulangan plat lantai. Margaretta J (2017) telah melakukan penelitian pada dua proyek konstruksi gedung bertingkat di Jakarta. Dalam penelitian ini terdapat dua cara yang digunakan untuk menghasilkan persentase penghematan, cara pertama yaitu berdasarkan diameter pekerjaan masing-masing, dan cara kedua yaitu dengan mengerjakan berdasarkan diameter tulangan yang digabungkan. cara pertama didapatkan penghematan sebesar 3,6\% untuk proyek $X$ dan 3,9\% untuk proyek $Y$, sedangkan untuk cara kedua didapatkan penghematan sebesar $4 \%$ untuk proyek $X$ dan $4,51 \%$ untuk proyek $Y$. Berdasarkan hasil tersebut, maka disimpulkan bahwa cara pertama yang lebih layak untuk dilaksanakan di lapangan karena tidak membutuhkan waktu pengerjaan yang lama.

Isaac (2020), pada evaluasi perhitungan material dan biaya besi pada proyek rumah dinas Polres Kota Sukabumi menyatakan akan terjadi pengehmatan sebsar Rp. 31.313.820,- jika perhitungan BBS dilakukan sejak tahap perencanaan proyek. Menurut Julsena (2018), faktor sisa material yang dominan selama pelaksanaan proyek konstruksi gedung di Provinsi Aceh adalah faktor residual dengan indikatornya kesalahan pada saat memotong material. Menurut Visaretri (2017), penggunaan program bantu Add-in Solver mampu mengoptimasi sisa material baja tulangan dengan cukup baik serta menghasilkan waste baja tulangan minimum. Presentase rata-rata penghematan baja tulangan pada masing-masing diameter yaitu pada $\varnothing 8$ sebesar $25,99 \%$, D10 sebesar 5,15\%, D13 sebesar 19,09\%, D16 sebesar 27,268\%, D19 sebesar 17,03\%. Menurut Kork. M (2013), penggunaan Excel Solver dapat mengoptimasi waste pada pemotongan tulangan. Persentase penghematan besi tulangan berdiameter 22 terjadi penghematan $2,07 \%$, besi tulangan berdiameter16 hemat $3,76 \%$, besi tulangan berdiameter 13 hemat $3,52 \%$, besi tulangan berdiameter 12 hemat $4,76 \%$ besi tulangan berdiameter 10 hemat $2,43 \%$. Upayayang dapat dilakukan untuk mengurangi timbulnya construction waste menurut Wahyudi (2016) adalah dengan meminimalkan perubahan desain dan pengendalian material. Kenny (2018)

Beberapa tujuan yang akan dicapai dalam penelitian ini yang pertama, menghasilkan optimasi pemotongan besi untuk memperoleh buangan sisa besi terkecil dan jumlah yang sesuai dengan 
kebutuhan. Kedua, mengetahui besarnya penghematan yang dapat dilakukan dengan menerapkan metode Linear Programming untuk optimasi pemotongan besi. Ketiga, mengetahui biaya yang dapat dihemat setelah melakukan optimasi pemotongan besi dengan metode Linear Programming

\section{Metode Penelitian}

Penelitian dilakukan berdasarkan studi kasus pembangunan Gedung Puskesmas Kampung Dalam Kabupaten Padang Pariaman mulai dari pengumpulan data proyek berupa data umum proyek, data mengenai jumlah dan ukuran besi tulangan yang digunakan, gambar rencana dan analisa harga satuan pekerjaan. Selanjutnya dilakukan perhitungan rekapitulasi bar bending schedule pada pekerjaan pembesian pondasi, kolom, balok, sloof dan pelat lantai yang ada di lapangan. Kemudian dilakukan perhitungan ulang dengan meggunakan metode linear programming (Syahputra, 2015) dengan bantuan program Add-In Solver pada Microsoft Excel, setelah itu dibandingkan hasil dari program tersebut dengan rekapitulasi bar bending schedule di lapangan.

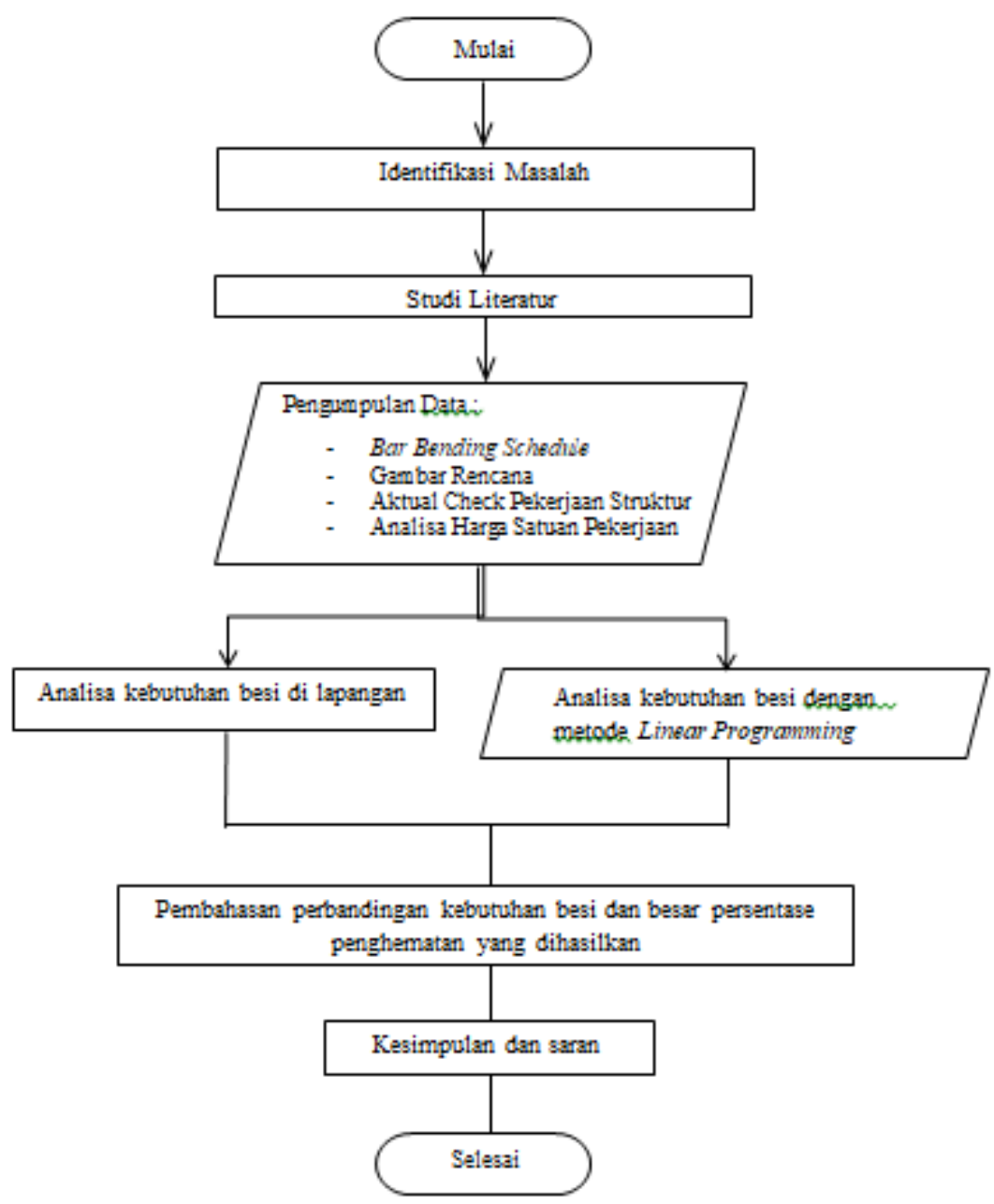

Gambar 1. Diagram Alir Penelitian 


\section{Hasil dan Pembahasan}

\subsection{Hasil Analisis Lapangan}

Kebutuhan besi di lapangan beserta waste yang dihasilkan pada masing-masing pekerjaan dan diameter didapatkan dari data bar bending schedule. Rekapitulasinya dapat dilihat pada tabel 1 berikut ini.

Tabel 1. Rekapitulasi Kebutuhan Besi di Lapangan

\begin{tabular}{|c|c|c|c|c|c|c|c|}
\hline Pek & D & $\begin{array}{l}\text { Kebutuhan } \\
\text { Besi di } \\
\text { Lapangan } \\
\text { (batang) }\end{array}$ & $\begin{array}{c}\text { Waste } \\
\text { besi di } \\
\text { Lapangan } \\
\text { (m) }\end{array}$ & Pek & D & $\begin{array}{l}\text { Kebutuhan } \\
\text { Besi di } \\
\text { Lapangan } \\
\text { (batang) }\end{array}$ & $\begin{array}{c}\text { Waste } \\
\text { besi di } \\
\text { Lapangan } \\
\text { (m) }\end{array}$ \\
\hline \multirow{6}{*}{ Balok } & 8 & 55 & 12,18 & \multirow{2}{*}{$\begin{array}{l}\text { Plat } \\
\text { lantai }\end{array}$} & 8 & 38 & 52,42 \\
\hline & 10 & 294 & 98,44 & & 10 & 836 & 759,58 \\
\hline & 12 & 136 & 170 & \multirow{2}{*}{ Pondasi } & 8 & 28 & 38,88 \\
\hline & 13 & 28 & 40,96 & & 12 & 292 & 493,17 \\
\hline & 16 & 77 & 158,6 & \multirow{4}{*}{ Sloof } & 8 & 9 & 10,03 \\
\hline & 19 & 158 & 367,071 & & 10 & 80 & 10,01 \\
\hline \multirow{4}{*}{ Kolom } & 8 & 61 & 6,01 & & 12 & 44 & 115,91 \\
\hline & 10 & 259 & 244,96 & & 16 & 81 & 89,63 \\
\hline & 12 & 127 & 404,31 & & & & \\
\hline & 16 & 378 & 980,97 & & & & \\
\hline
\end{tabular}

Sumber : Analisa Data Lapangan

\subsection{Linear Programming}

Memodelkan permasalahan Linear Programming dari tabel 1 untuk di analisa menggunakan bantuan Solver-Add In sehingga didapatkan pola pemotongan yang sudah dioptimasi maka perlu dilakukan langkah-langkah berikut ini :

a. Variabel keputusan

Tabel 2 Alternatif Pemotongan Besi Tulangan Pondasi Berdiameter 12

PROSES INPUT DATA SOLVER DIAMETER 12

\begin{tabular}{ccccc}
\hline \multirow{2}{*}{ Kode } & \multirow{2}{*}{ Alternatif } & \multicolumn{2}{c}{ Panjang Potongan } & \multirow{2}{*}{ SISA (M) } \\
& & 3,4 & 1,52 & \\
X1 & 1 & 3 & 1 & 0,28 \\
X2 & 2 & 2 & 3 & 0,64 \\
X3 & 4 & 0 & 7 & 1,36 \\
X4 & 5 & 5 & 1 & 1 \\
& KEBUTUHAN & 612 & 479 & \\
\hline
\end{tabular}


Variabel keputusan yang dimaksud adalah jumlah besi tulangan pada diameter tertentu dengan pola/alternatif pemotongan besi yang berbeda-beda sesuai dengan kebutuhan. Pembuatan alternatif pemotongan dengan memperhatikan kombinasi-kombinasi yang menghasilkan sisa pemotongan yang terbuang seminimal mungkin. Pada alternatif pemotongan besi tulangan pondasi berdiameter 12, didapatkan 4 alternatif/pola pemotongan yang berbeda. Dimana terdapat 2 macam potongan pada diameter ini. Masing-masing potongan memiliki kebutuhan yang berbeda-beda. Selanjutnya, tabulasi dari alternatif pemotongan besi tulangan pondasi berdiameter 12 dapat dilihat pada tabel 2 berikut ini.

b. Fungsi Tujuan

Fungsi tujuan dari penelitian ini adalah mengetahui nilai minimum total besi sisa dengan menggunakan metode Linear Programming berdasarkan masing-masing pekerjaan dan diameter. Maka persamaan matematis optimasi pemotongan besi dari alternatif tersebut sebagai berikut.

$Z=0,28 X_{1}+0,64 X_{2}+1,36 X_{3}+1 X_{4}$

Tabel 3. Rangkuman Jumlah Variasi Panjang Potongan dengan Variabel Keputusan

\begin{tabular}{|c|c|c|c|}
\hline \multirow{2}{*}{ Pekerjaan } & \multirow{2}{*}{ Diameter } & \multicolumn{2}{|c|}{ Jumlah } \\
\hline & & Variasi Potongan & Variabel Keputusan \\
\hline \multirow{6}{*}{ Balok } & 8 & 2 & 1 \\
\hline & 10 & 4 & 4 \\
\hline & 12 & 21 & 15 \\
\hline & 13 & 6 & 5 \\
\hline & 16 & 6 & 4 \\
\hline & 19 & 4 & 2 \\
\hline \multirow{4}{*}{ Kolom } & 8 & 1 & 1 \\
\hline & 10 & 3 & 3 \\
\hline & 12 & 4 & 4 \\
\hline & 16 & 4 & 3 \\
\hline \multirow{2}{*}{ Plat lantai } & 8 & 6 & 6 \\
\hline & 10 & 20 & 21 \\
\hline \multirow{2}{*}{ Pondasi } & 8 & 2 & 1 \\
\hline & 12 & 3 & 2 \\
\hline \multirow{4}{*}{ Sloof } & 8 & 1 & 1 \\
\hline & 10 & 1 & 1 \\
\hline & 12 & 6 & 6 \\
\hline & 16 & 3 & 3 \\
\hline
\end{tabular}

c. Fungsi Kendala

Fungsi kendala yang dimaksud yaitu jumlah kebutuhan potongan dari masing-masing panjang potongan yang dianalisis. Pada tabel 2 alternatif pemotongan yang dapat dibuat yaitu 4 alternatif, sehingga ada 4 fungsi pembatas yang tercipta yaitu X1, X2, X3, dan X4. Sehingga fungsi kendalanya menjadi : 


$$
\begin{array}{ll}
X_{1}+X_{2}+X_{4} & \geq 612 \\
X_{1}+X_{2}+X_{3}+X_{4} & \geq 479
\end{array}
$$

Langkah selanjutnya yaitu melakukan optimasi dari persamaan matematis yang dibuat menggunakan bantuan fitur Solver-Add In.

\subsection{Analisa Hasil Optimasi Pemotongan Besi}

Optimasi pemotongan besi yang telah dilakukan pada setiap pekerjaan menghasilkan jumlah variabel keputusan yang berbeda untuk setiap pekerjaan dengan diameter masing-masing. Variabel keputusan ini menunjukkan jumlah alternatif/pola pemotongan yang akan dilaksanakan di lapangan nantinya. Rangkuman jumlah variasi panjang potongan dengan variabel keputusan yang dihasilkan dapat dilihat pada tabel 3 berikut ini.

Langkah pengolahan data yang sama dilakukan pada masing-masing diameter pada pekerjaan pondasi, sloof, kolom, balok dan plat lantai sehingga didapatkan hasil kebutuhan besi beserta sisa buangan besi yang dihasilkan menggunakan metode Linear Programming yang dapat dilihat pada tabel 4 berikut ini.

Tabel 4. Hasil Analisis Lapangan dan Linear Programming

\begin{tabular}{ccccccc}
\hline \multirow{2}{*}{ Pekerjaan } & D & \multicolumn{2}{c}{ Kebutuhan Besi (batang) } & \multirow{2}{*}{$\begin{array}{c}\text { Volume } \\
\text { Terpasang }\end{array}$} & \multicolumn{2}{c}{ Waste Besi (m) } \\
\cline { 3 - 4 } & & Lapangan & $\begin{array}{c}\text { Linear } \\
\text { Programming }\end{array}$ & (kg) & Lapangan & $\begin{array}{c}\text { Linear } \\
\text { Programming }\end{array}$ \\
\hline \multirow{5}{*}{ Balok } & 8 & 55 & 55 & 255,89 & 12,17 & 12,17 \\
& 10 & 294 & 289 & 2116,04 & 98,44 & 35,75 \\
& 12 & 136 & 131 & 1287,25 & 170 & 10,96 \\
& 13 & 28 & 28 & 307,43 & 40,96 & 40,96 \\
& 16 & 77 & 68 & 1207,8 & 158,6 & 66,6 \\
& 19 & 158 & 140 & 3403,56 & 367,07 & 151 \\
& 8 & 61 & 61 & 286,77 & 6,01 & 6,01 \\
Kolom & 10 & 259 & 241 & 1766,62 & 244,96 & 114,61 \\
& 12 & 127 & 105 & 994,38 & 404,31 & 16,56 \\
& 16 & 378 & 354 & 5609,6 & 980,97 & 516,26 \\
Plat lantai & 8 & 38 & 36 & 159,44 & 52,42 & 37,09 \\
& 10 & 836 & 787 & 5721,46 & 759,58 & 66,69 \\
& 8 & 28 & 28 & 117,38 & 38,88 & 38,88 \\
& 12 & 292 & 243 & 2673,73 & 493,17 & 137,97 \\
& 8 & 9 & 9 & 38,7 & 10,03 & 10,03 \\
& 10 & 80 & 80 & 586,15 & 10,01 & 10,01 \\
& 12 & 44 & 36 & 365,96 & 115,91 & 5,28 \\
& 16 & 81 & 64 & 1392,37 & 89,63 & 46,56 \\
\hline \multirow{6}{*}{ Sloof } & & & & & &
\end{tabular}

Pada tabel 4 dapat terlihat jumlah kebutuhan besi dalam satuan batang pada masing-masing diameter pekerjaan pondasi, sloof, kolom, balok dan plat lantai dengan analisa di lapangan dan dengan menggunakan metode Linear Programming. Hal ini disertai dengan besaran waste besi 
yang dihasilkan dalam satuan meter. Selanjutnya, kebutuhan besi ini akan dikonversikan kedalam satuan kilogram $(\mathrm{kg})$ yang dapat dilihat pada tabel 5 berikut ini.

Tabel 5. Hasil Analisa dalam Satuan Kilogram

\begin{tabular}{|c|c|c|c|c|c|}
\hline \multirow{2}{*}{ Diameter } & \multicolumn{2}{|c|}{ Kebutuhan Besi (kg) } & \multirow{2}{*}{$\begin{array}{l}\text { Volume } \\
\text { Terpasang } \\
\text { (kg) }\end{array}$} & \multicolumn{2}{|c|}{ Waste Besi (kg) } \\
\hline & Lapangan & Linear Programming & & Lapangan & Linear Programming \\
\hline 8 & 905,34 & 895,86 & 858,179 & 47,207 & 41,152 \\
\hline 10 & 10876,476 & 10343,388 & 10190,269 & 686,715 & 149,9 \\
\hline 12 & 6382,944 & 5487,84 & 5321,322 & 1050,85 & 166,425 \\
\hline 13 & 350,112 & 350,112 & 307,433 & 42,68 & 42,68 \\
\hline 16 & 10149,696 & 9202,896 & 8209,765 & 1939,672 & 993,225 \\
\hline 19 & 4220,496 & 3739,68 & 3403,556 & 817,098 & 336,126 \\
\hline TOTAL & 32885,064 & 30019,776 & 28290,524 & 4584,222 & 1729,508 \\
\hline
\end{tabular}

Berdasarkan tabel 5 dapat diketahui kebutuhan besi di lapangan sebesar 32.885,064 kg dengan waste besi sebesar 4584,222 . Sehingga persentase waste besi tulangan dapat dihitung sebagai berikut.

$\%$ waste di lapangan $=\frac{\text { jumlah } \text { waste besi }}{\text { total kebutuhan besi }}$

$\%$ waste di lapangan $=\frac{4584,222 \mathrm{~kg}}{32885,064 \mathrm{~kg}} \times 100 \%$

$\%$ waste di lapangan $=13,94 \%$

Persentase sisa buangan besi di lapangan sebesar 13,94\%. Selanjutnya, persentase sisa buangan dengan menggunakan metode Linear Programming dengan bantuan Solver-Add In dihitung untuk dibandingankan dengan persentase sisa buangan yang terjadi di lapangan.

$\%$ waste besi dengan metode LP $=\frac{\text { jumlah waste besi }}{\text { total kebutuhan besi }}$

$\%$ waste di lapangan $=\frac{1729,508 \mathrm{~kg}}{30019,776 \mathrm{~kg}} \times 100 \%$

$\%$ waste di lapangan $=5,761 \%$

Persentase waste besi dengan menggunakan metode Linear Programming mendapatkan hasil sebesar $5,761 \%$. Berdasarkan hasil tersebut, dapat disimpulkan bahwa metode Linear Programming telah berhasil meminimalisasi sisa potongan-potongan material besi tulangan. Tabel 5 juga dapat menunjukkan bahwa penggunaan metode Linear Programming juga menghasilkan jumlah kebutuhan besi yang lebih kecil dibanding kebutuhan besi di lapangan. Sehingga, terjadi penghematan kebutuhan besi terhadap lapangan pada masing-masing pekerjaan yang disajikan dalam tabel 6 berikut ini. 
Tabel 6. Hasil Analisa Penghematan Kebutuhan Besi Terhadap Lapangan

\begin{tabular}{cccc} 
Pekerjaan & Lapangan (Kg) & $\begin{array}{c}\text { Linear } \\
\text { Programming (kg) }\end{array}$ & $\begin{array}{c}\text { Penghematan Besi } \\
\text { Terhadap Lapangan (kg) }\end{array}$ \\
\hline Balok & 9915 & 9173,83 & 741,54 \\
Kolom & 10718 & 9895,73 & 822,17 \\
Plat lantai & 6370 & 5997,59 & 372,28 \\
Pondasi & 3244 & 2722,13 & 522,14 \\
Sloof & 2638 & 2230,5 & 407,16 \\
Jumlah & 32885,06 & 30019,78 & 2865,288 \\
\hline
\end{tabular}

Optimasi pemotongan besi yang dilakukan menimbulkan adanya penghematan kebutuhan besi, dimana hal ini akan berdampak terhadap biaya pelaksanaan. Besarnya biaya yang dapat dihemat dengan menerapkan optimasi pemotongan besi menggunakan metode Linear Programming mengacu pada Analisa Harga Satuan Pekerjaan Tahun 2019 Kab. Padang Pariaman, sehingga didapat hasil pada tabel 7 berikut ini.

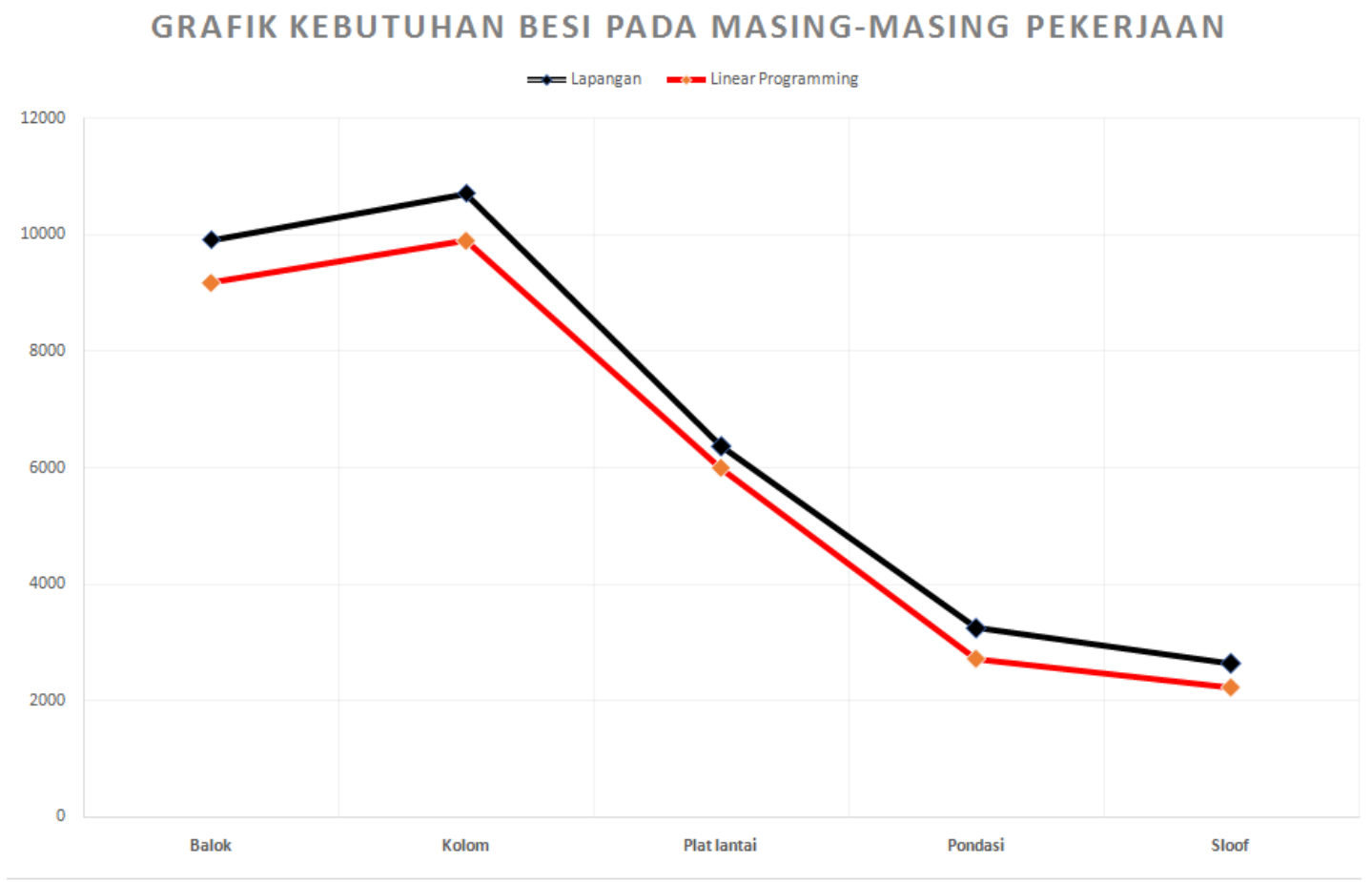

Gambar 2. Grafik Kebutuhan Besi Analisa Linear Program terhadap Lapangan 
Tabel 7 Hasil Analisa Penghematan Terhadap Biaya Pelaksanaan

\begin{tabular}{|c|c|c|c|c|c|c|c|}
\hline \multirow{2}{*}{ 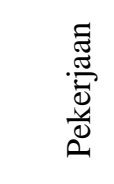 } & \multirow[b]{2}{*}{$\mathrm{D}$} & \multicolumn{2}{|c|}{ Kebutuhan Besi (kg) } & \multirow{2}{*}{$\begin{array}{l}\text { Harga } \\
\text { Satuan } \\
\text { Bahan } \\
\text { Per Kg }\end{array}$} & \multicolumn{3}{|c|}{ Biaya (Rp) } \\
\hline & & Lapangan & $\begin{array}{l}\text { Linear } \\
\text { Program- } \\
\text { ming }\end{array}$ & & Lapangan & $\begin{array}{c}\text { Linear } \\
\text { Programming }\end{array}$ & $\begin{array}{c}\text { Penghematan } \\
\text { Biaya }\end{array}$ \\
\hline \multirow{6}{*}{$\begin{array}{l}\frac{y}{0} \\
\frac{0}{0}\end{array}$} & 8 & 260,7 & 260,7 & Rp11.550 & Rp3.011.085 & Rp3.011.085 & Rp \\
\hline & 10 & 2176,78 & 2139,76 & Rp11.550 & Rp25.141.763 & Rp24.714.182 & Rp427.581 \\
\hline & 12 & 1449,22 & 1395,94 & Rp11.550 & Rp16.738.445 & Rp16.123.061 & Rp615.384 \\
\hline & 13 & 350,11 & 350,11 & Rp11.550 & Rp4.043.794 & Rp4.043.794 & $\mathrm{Rp}$ \\
\hline & 16 & 1458,07 & 1287,65 & Rp11.550 & Rp16.840.732 & Rp14.872.334 & Rp1.968.397 \\
\hline & 19 & 4220,5 & 3739,68 & Rp11.550 & Rp48.746.729 & Rp43.193.304 & Rp5.553.425 \\
\hline \multirow{4}{*}{$\begin{array}{l}\Xi \\
\frac{0}{0} \\
\frac{1}{1}\end{array}$} & 8 & 289,14 & 289,14 & Rp11.550 & Rp3.339.567 & Rp3.339.567 & $\mathrm{Rp}$ \\
\hline & 10 & 1917,64 & 1784,36 & Rp11.550 & Rp22.148.696 & Rp20.609.404 & Rp1.539.292 \\
\hline & 12 & 1353,31 & 1118,88 & Rp11.550 & Rp15.630.754 & Rp12.923.064 & Rp2.707.690 \\
\hline & 16 & 7157,81 & 6703,34 & Rp11.550 & Rp82.672.682 & Rp77.423.623 & Rp5.249.059 \\
\hline \multirow{2}{*}{ 离营 } & 8 & 180,12 & 170,64 & Rp11.550 & Rp2.080.386 & Rp1.970.892 & Rp109.494 \\
\hline & 10 & 6189,74 & 5826,95 & Rp11.550 & Rp71.491.543 & Rp67.301.249 & Rp4.190.294 \\
\hline \multirow{3}{*}{$\begin{array}{l}\overrightarrow{\tilde{g}} \\
\frac{1}{0} \\
\overrightarrow{0} \\
0\end{array}$} & 8 & 132,72 & 132,72 & Rp11.550 & Rp1.532.916 & Rp1.532.916 & $\mathrm{Rp}$ \\
\hline & 12 & 3111,552 & 2589,41 & Rp11.550 & Rp35.938.426 & Rp29.907.662 & Rp6.030.763 \\
\hline & 8 & 42,66 & 42,66 & Rp11.550 & Rp492.723 & Rp492.723 & $\mathrm{Rp}$ \\
\hline \multirow{3}{*}{$\frac{4}{8}$} & 10 & 592,32 & 592,32 & Rp11.550 & Rp6.841.296 & Rp6.841.296 & $\mathrm{Rp}$ \\
\hline & 12 & 468,86 & 383,62 & Rp11.550 & Rp5.415.379 & Rp4.430.765 & Rp984.614 \\
\hline & 16 & 1533,82 & 1211,9 & Rp11.550 & Rp17.715.575 & Rp13.997.491 & Rp3.718.084 \\
\hline \multicolumn{2}{|c|}{ Jumlah } & 32885,06 & 30019,78 & & Rp379.822.489 & Rp346.728.413 & Rp33.094.076 \\
\hline
\end{tabular}

\section{Kesimpulan}

Optimasi pemotongan besi tulangan menggunakan metode linear programming didapatkan persentase sebesar $5,76 \%$. Sedangkan persentase waste besi sebelum dilakukan optimasi yaitu sebesar 13,94\%. Optimasi pemotongan besi tulangan menggunakan metode linear programming menghasilkan jumlah kebutuhan besi yang lebih kecil dibanding kebutuhan besi di lapangan. Kebutuhan besi di lapangan sebesar 32885,06 kg, sedangkan kebutuhan besi dengan menerapkan metode linear programming yaitu sebesar $30019,78 \mathrm{~kg}$. Dimana terjadi selisih kebutuhan besi terhadap lapangan sebesar $2865,288 \mathrm{~kg}$. Sehingga persentase penghematan kebutuhan besi terhadap lapangan yang terjadi yaitu sebesar $8,71 \%$. Besarnya biaya pelaksanaan yang dapat dihemat setelah dilakukan optimasi menggunakan metode Linear Programming pada pemotongan besi tulangan pekerjaan pondasi, sloof, kolom, balok dan plat lantai yaitu sebesar Rp 33.094.076 (tiga puluh tiga juta sembilan puluh empat ribu tujuh puluh enam rupiah). 


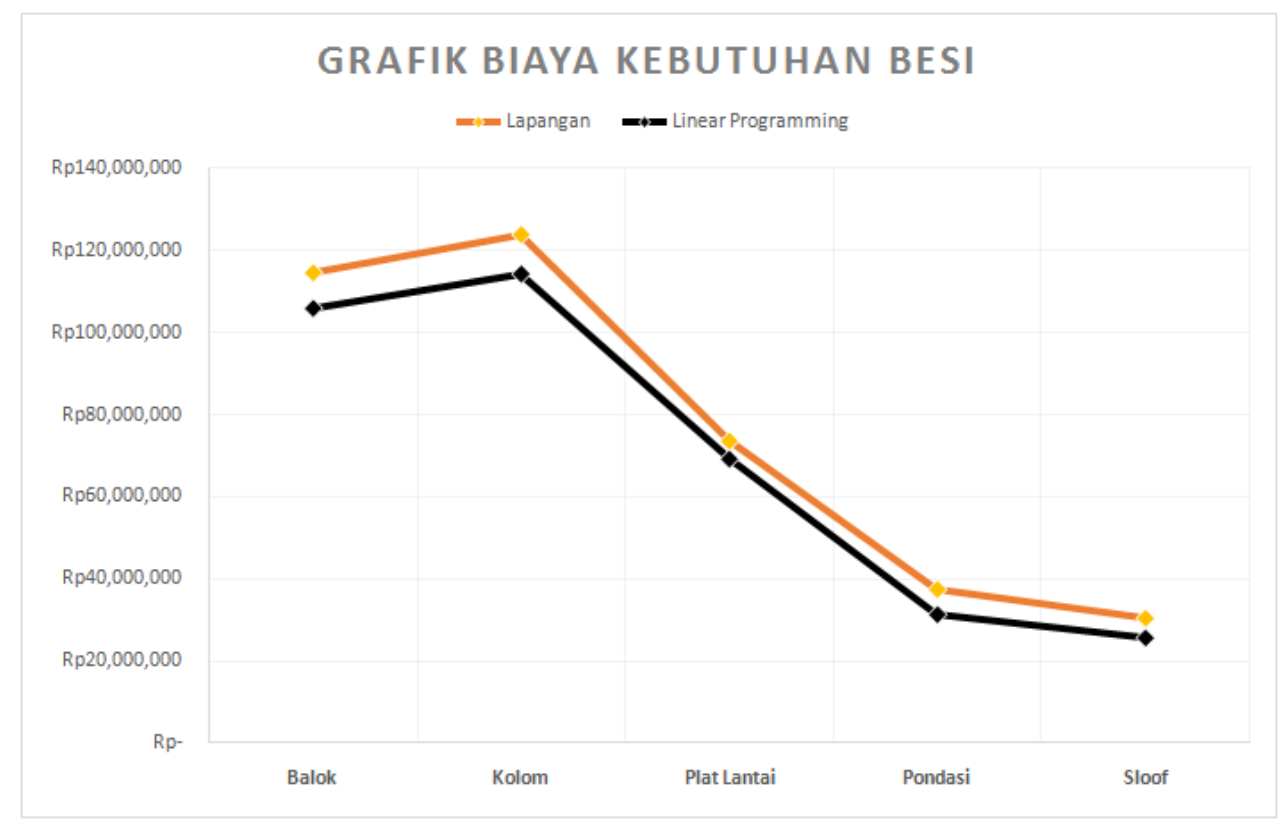

Gambar 2. Grafik Biaya Kebutuhan Besi Analisa Linear Program terhadap Lapangan

\section{Saran}

Pada penelitian selanjutnya, lokasi penelitian yang dipilih dapat dilakukan pada proyek dengan skala lebih besar dan item pekerjaan yang lebih kompleks. Untuk mendapatkan hasil yang optimal dibutuhkan pembuatan kombinasi yang lebih teliti dan bervariasi lagi serta akan lebih efektif jika ada kombinasi penggunaan program tambahan lain menghasilkan alternatif-alternatif pemotongan besi tulangan sehingga tidak perlu berulang-ulang pembuatannya.

\section{Ucapan Terima Kasih}

Kepada semua pihak yang telah membantu selama penelitian, penulis mengucapkan terima kasih kepada: Segenap Pimpinan Jurusan Teknik Sipil Politeknik Negeri Padang, Ibu Monika Natalia, ST., MT, selaku ketua program Studi DIV Manajemen Rekayasa Konstruksi Politeknik Negeri Padang. Bapak Jajang Atmaja, ST., MSi dan Bapak Fauna Adibroto, ST., MT selaku dosen pembimbing yang telah banyak memberikan bimbingan dan arahan, serta masukan yang sangat berarti bagi penulis. Rekan-rekan mahasiswa teknik sipil angkatan 2016 atas kerja sama dan bantuannya.

\section{Daftar Pustaka}

I Gusti Putu Adi, dkk, 2018, Penanganan Waste Material pada proyek Konstruksi Gedung Bertingkat, Jurnal Spektran, Vol 6 No 2, Juli 2018, hal 176-185, e-ISSN : 2302-2590, https://ojs.unud.ac.id/index.php/jsn/article/view/42308/25723

Isaac DI, 2020, Evaluasi Perhitungan Material dan Biaya Besi pada Proyek Rumah Dinas Polres Kota Sukabumi, Jurnal Student Teknik Sipil Volume 1 No.2, e-ISSN: 2686-5033, hal 82-86, https://jurnal.ummi.ac.id/index.php/JSTS/article/view/676 
Julsena dkk, 2018, Faktor Sisa Material yang mempengaruhi biaya pada Pelaksanaan Proyek Konstruksi Gedung di Provinsi Aceh, Jurnal Arsip Rekayasa Sipil dan Perencanaan 1(4): 148-155, E-ISSN: 2615-1340, http://jurnal.unsyiah.ac.id/JARSP/article/view/12465

Kork, M., 2013, Perhitungan Kebutuhan Tulangan Besi dengan Memperhitungkan Optimasi Waste Besi pada Pekerjaan Balok dengan Program Microsoft Excel, e-Jurnal Matriks Teknk Sipil, hal 290-295, https://jurnal.uns.ac.id/matriks/article/view/37533/24761

Margaretta J dkk, 2017, Penerapan Metode Linear Programming untuk Analisis Pemotongan Besi Tulangan pada Proyek Bangunan Gedung di Jakarta, Jurnal Muara Sains Volume 1, No. 2 Oktober 2017, halaman 51-61, ISSN-I-2579-6410, https://journal.untar.ac.id/index.php/jmistki/article/view/1029/0

Sabry, S, 2013, Model Optimasi Pemotongan Besi Tulangan Pelat Lantai dengan Program Linear., e-Jurnal Matriks Teknik Sipil, 283-289, https://jurnal.uns.ac.id/matriks/article/view/37532/24760

Syahputra, E, 2015, Program Linier, Medan, Unimed Press

Visaretri dkk, 2017, Penghitungan Optimasi Baja Tulangan pada Pelerjaan Pelat dan Balok dengan menggunakan Microsoft Excel dan Autocad (Studi Kasus Pembangunan Apartemen Gunawangsa Tidar Surabaya), e-Jurnal Matriks Teknik Sipil, hal 1102-1111, e-ISSN: 27234223 https://jurnal.uns.ac.id/matriks/article/view/36744

Wahyudi, N. .2016, Kajian Pengelolaan Construction Waste Dalam Konstruksi Bangunan Gedung, Prosiding Seminar Nasional Teknik Sipil 2016, hal 210-217, ISSN:2459-9727, Fakultas Teknik Universitas Muhammadiyah Surakarta, https://publikasiilmiah.ums.ac.id/bitstream/handle/11617/7500/Paper_\%28MK10\%29.pdf?sequence $=1 \&$ is Allowed $=\mathrm{y}$

Waluyo, 2017, Analisa Sisa Material Proyek Pembangunan Hotel Kawasan Marvell City, Jurusan Teknik Sipil, Institut Teknologi Sepuluh November, http://repository.its.ac.id/1971/ 